\title{
Work Capacity after Iron Treatment as a Function of Hemoglobin and Iron Deficiency
}

\author{
Y. OHIRA, ${ }^{1,2}$ V. R. EdGerton,,${ }^{1,3}$ G. W. GARDNER, ${ }^{1}$ \\ K. A. Gunawardena ${ }^{4}$ B. Senewiratne, ${ }^{4}$ \\ and S. IKAWA ${ }^{5,6}$ \\ ${ }^{1}$ Department of Kinesiology, University of California, \\ Los Angeles, California 90024, U.S.A. \\ ${ }^{4}$ Department of Medicine, University of Sri Lanka, Sri Lanka \\ ${ }^{5}$ Department of Clinical Medicine, \\ The Jikei University School of Medicine, Tokyo 105, Japan
}

(Received April 15, 1980)

\begin{abstract}
Summary The relative importance of hemoglobin $(\mathrm{Hb})$ and non- $\mathrm{Hb}$ iron for physical work capacity was studied in 45 adult male and female subjects, with a range of $\mathrm{Hb}$ and serum iron levels. Maximal work capacity, heart rate, venous blood lactate and serum protein were measured before and after 1 week of treatment with Imferon, i.v. Even though some non- $\mathrm{Hb}$ related effects on parameters indicative of maximal work capacity were found, the main factor was Hb related. Subjects with low $\mathrm{Hb}$-high serum iron worked longer than ones with low Hb-low iron. When the work performed was similar, the marginal Hb-low iron group had a higher blood lactate concentration than the high $\mathrm{Hb}$-high iron and marginal Hb-high iron groups. The coefficient of correlation between serum iron and post-exercise lactate levels was $-0.41(p<0.05)$. Even though neither of these groups showed a $\mathrm{Hb}$ response within 1 week of iron treatment, the initial low serum iron groups had significantly lower heart rates at a given work load relative to subjects with high iron but with a similar $\mathrm{Hb}$ level. This occurred both at rest and during light to heavy exercise. These results suggest that a rather rapid benefit of iron treatment is gained in iron-deficient subjects with severe and moderate anemia which cannot be accounted for by $\mathrm{Hb}$ changes. Although the primary factor which affects the physical work capacity of iron-deficient anemic subjects seems to be the $\mathrm{Hb}$ level, there also seems to be a significant non- $\mathrm{Hb}$ related effect of iron treatment as well.
\end{abstract}

Key Words work capacity, heart rate, lactate, hemoglobin, iron deficiency, iron treatment

2 大平充宣, 6 井川幸雄

${ }^{3}$ Member of the Brain Research Institute, University of California, Los Angeles, California 90024, U.S.A. 
Hemoglobin $(\mathrm{Hb})$ concentration in the blood is closely related to work performance capacity (1-4). Treatment of iron-deficient anemic subjects with iron can result in an improvement in work capacity within 4 days. The heart rate response to exercise following iron treatment suggests some non- $\mathrm{Hb}$ as well as $\mathrm{Hb}$ related effects $(5,6)$. However, it appears that the Hb-related effects of iron treatment are considerably more critical in work capacity on the treadmill than non$\mathrm{Hb}$ factors. For example, the work capacity of iron-deficient anemic subjects transfused with whole blood is improved within $24 \mathrm{hr}$ to the level predicted solely on the basis of the $\mathrm{Hb}$ level alone (unpublished data).

Therefore, in order to determine the relative importance of $\mathrm{Hb}$ and non- $\mathrm{Hb}$ responses to iron treatment with respect to work performance, subjects with a range in $\mathrm{Hb}$ concentrations and with either normal or low serum iron were studied.

\section{METHODS}

In 10 male and 35 female hospital patients in Kandy General Hospital, Sri Lanka, $\mathrm{Hb}$ (cyanmethemoglobin method) and serum iron (7) were determined. None of the subjects had been treated for anemia for at least 1 year. The subjects were divided into the following five groups: 1) high $\mathrm{Hb}(\geq 13.0 \mathrm{~g} / 100 \mathrm{ml})$-high serum iron ( $\geq 44 \mu \mathrm{g} / 100 \mathrm{ml}) ; 2)$ marginal $\mathrm{Hb}(13.0>\mathrm{Hb} \geq 10.0 \mathrm{~g} / 100 \mathrm{ml})$-high serum iron; 3) marginal Hb-low serum iron $(<44 \mu \mathrm{g} / 100 \mathrm{ml})$; 4) low $\mathrm{Hb}(<10.0 \mathrm{~g} / 100 \mathrm{ml})$-high serum iron; and 5) low $\mathrm{Hb}$-low serum iron. The mean values of $\mathrm{Hb}$ and serum iron of these groups are shown in Table 1. Voluntary consents to participate were obtained from each individual after the experimental procedures and design were explained. Subjects were allowed to withdraw at any time during the experiment.

Effects of 1 week of iron treatment on the maximal work capacity, heart rate and venous blood lactate, and heart rate response to a given intensity of exercise and selected hematological characteristics were studied. Pre-tests were performed

Table 1. The characteristics of subjects.

\begin{tabular}{|c|c|c|c|c|c|}
\hline Group & $\begin{array}{c}n \\
\text { (sex) }\end{array}$ & $\begin{array}{c}\text { Age } \\
\text { (year) }\end{array}$ & $\begin{array}{l}\text { Weight } \\
(\mathrm{kg})\end{array}$ & $\begin{array}{c}\mathrm{Hb} \\
(\mathrm{g} / 100 \mathrm{ml})\end{array}$ & $\begin{array}{c}\mathrm{Fe} \\
(\mu \mathrm{g} / 100 \mathrm{ml})\end{array}$ \\
\hline H.Hb-H.Fe & $5(\mathrm{M}), 17(\mathrm{~F})$ & $43.1 \pm 3.4$ & $44.0 \pm 1.6$ & $14.1 \pm 0.2$ & $98.0 \pm 6.1$ \\
\hline M.Hb-H.Fe & $2(\mathrm{M}), 5(\mathrm{~F})$ & $39.9 \pm 7.6$ & $43.5 \pm 1.8$ & $11.9 \pm 0.2$ & $84.0 \pm 11.3$ \\
\hline M.Hb-L.Fe & $5(\mathrm{~F})$ & $48.6 \pm 9.0$ & $38.9 \pm 4.2$ & $11.8 \pm 0.3$ & $29.6 \pm 3.4$ \\
\hline L.Hb-H.Fe & $1(\mathrm{M}), 4(\mathrm{~F})$ & $42.8 \pm 7.9$ & $44.1 \pm 2.3$ & $7.5 \pm 0.8$ & $73.7 \pm 9.3$ \\
\hline L.Hb-L.Fe & $2(\mathrm{M}), 4(\mathrm{~F})$ & $54.7 \pm 5.4$ & $38.2 \pm 1.0$ & $6.4 \pm 0.9$ & $28.5 \pm 4.4$ \\
\hline
\end{tabular}

Mean \pm SEM. $n$, number of subjects; $H$, high; $M$, marginal; L, low; Hb, hemoglobin; Fe, serum iron. 
twice on separate days. In the morning approximately $3 \mathrm{ml}$ of blood was withdrawn from the brachial vein while the subject was in a supine position. Hemoglobin, serum iron, total protein (refractometer), protein fractions (cellulose acetate electrophoresis), and haptoglobin $(8)$ were determined. Treadmill exercise was performed to determine the maximal work capacity and heart rate response to exercise. The work load was increased every 2 min by changing the speed and grade of the treadmill as shown in the previous study(5). The initial work load was $1.1 \mathrm{~km} / \mathrm{hr}$ at $0 \%$ grade and the maximum load attainable was $6.4 \mathrm{~km} / \mathrm{hr}$ at $20 \%$ grade. The exercise was terminated when the subject 1) chose to discontinue due to fatigue, 2) had completed the maximum exercise time of $24 \mathrm{~min}, 3$ ) had reached the heart rate which was $95 \%$ of maximum as predicted for age, 4) produced an abnormal electrocardiogram. Post-exercise blood samples (approximately $1 \mathrm{ml}$ ) for $\mathrm{Hb}$, lactate $(9)$ and serum protein determination were obtained 2 min after recovery.

All subjects were treated with Imferon i.v. as described previously(5). The determination of hematological and physiological parameters were repeated every other day for either 7 or 8 days after iron treatment. Because clear effects on work capacity and heart rate response within 4 days after iron treatment had been observed previously $(5,6)$, the current experiment was carried out for only 1 week. Pre-exercise blood samples were not taken in the tests carried out after iron treatment.

\section{RESULTS}

None of the subjects were protein deficient. Although the low Hb-low serum iron group had significantly lower serum protein levels than the low Hb-high serum iron group $(p<0.05)$, all values were within the normal range. The haptoglobin levels were significantly lower in the anemic subjects with high serum iron than in anemic subjects with low serum iron, suggesting some degree of hemolytic anemia $(10,11)$.

Changes in $\mathrm{Hb}$ following iron treatment are shown in Fig. 1. With one exception for all of the mean $\mathrm{Hb}$ levels, there were no significant increases within 8 days after iron treatment. Both anemic groups $(n=5$ and $n=6)$ showed a tendency to have elevated $\mathrm{Hb}$ levels within 3-8 days but these changes were insignificant $(p>0.05)$. Figure 2 shows that the subjects with the low $\mathrm{Hb}$ and serum iron worked for a significantly less time on the treadmill than any of the other four groups. Considering the total number of work tests administered over the 8 days after iron treatment, the performance of the subjects with a low $\mathrm{Hb}$ and high serum iron was superior to that of the anemic subjects who also had low serum iron and was inferior to that of all other subjects having a higher $\mathrm{Hb}$ regardless of their serum iron levels. The increase in work time within 7-8 days after iron treatment was greater for the two most anemic groups. There was a tendency for all groups to increase their work time, demonstrating some degree of adaptation to the treadmill tests.

Vol. 27, No. 2, 1981 


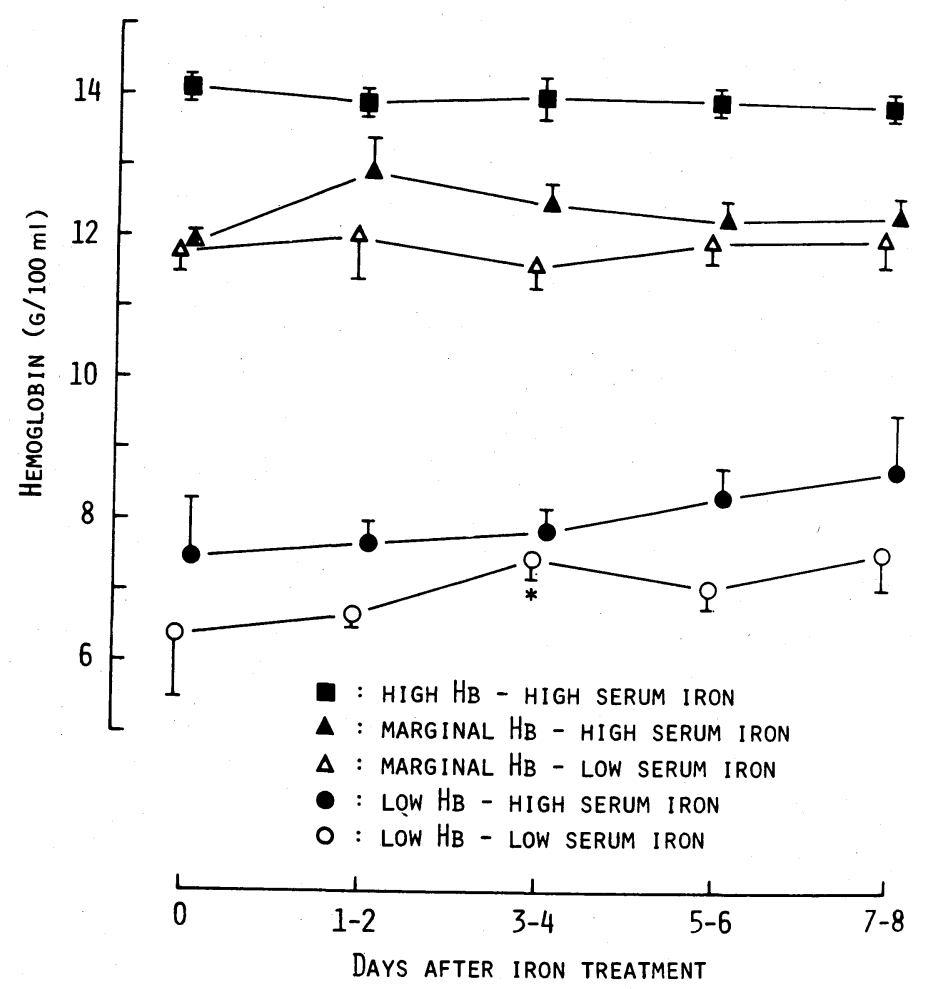

Fig. 1. Changes in mean hemoglobin concentration in response to iron treatment $( \pm \mathrm{SEM}){ }^{*} p<0.05$ by a paired $t$-test between the values before and each day after treatment.

However, the lack of a change in the heart rate response to a given work load for the normal $\mathrm{Hb}$ group with normal serum iron and the marginal $\mathrm{Hb}$ group with normal serum iron (Figs. 3-5) suggests that their longer work time on the treadmill was due to psychological rather than physiological adjustment to the work.

Figures 3-5 show changes in heart rate at rest and during exercise at a low and a high work intensity. The heart rate of the marginal $\mathrm{Hb}$ group with low serum iron tended to decrease sooner (1-2 days after treatment) and to a greater degree than in the more severely anemic subjects who also had low serum iron. No heart rate changes were observed during the 7-8 day post-treatment period in subjects with normal or marginal $\mathrm{Hb}$ and with normal serum iron levels.

Post-exercise venous blood lactate before and after iron treatment is shown in Table 2. These data show that the marginal Hb-low iron group had higher levels than any of the other groups. The lower the serum iron, the higher the lactate production in response to exercise $(r=-0.41, p<0.05)$. The low Hb-high iron group had higher lactate than the low Hb-low iron group $(p<0.05)$. In this case it should be recalled that the duration of the exercise differed among the groups (Fig. 


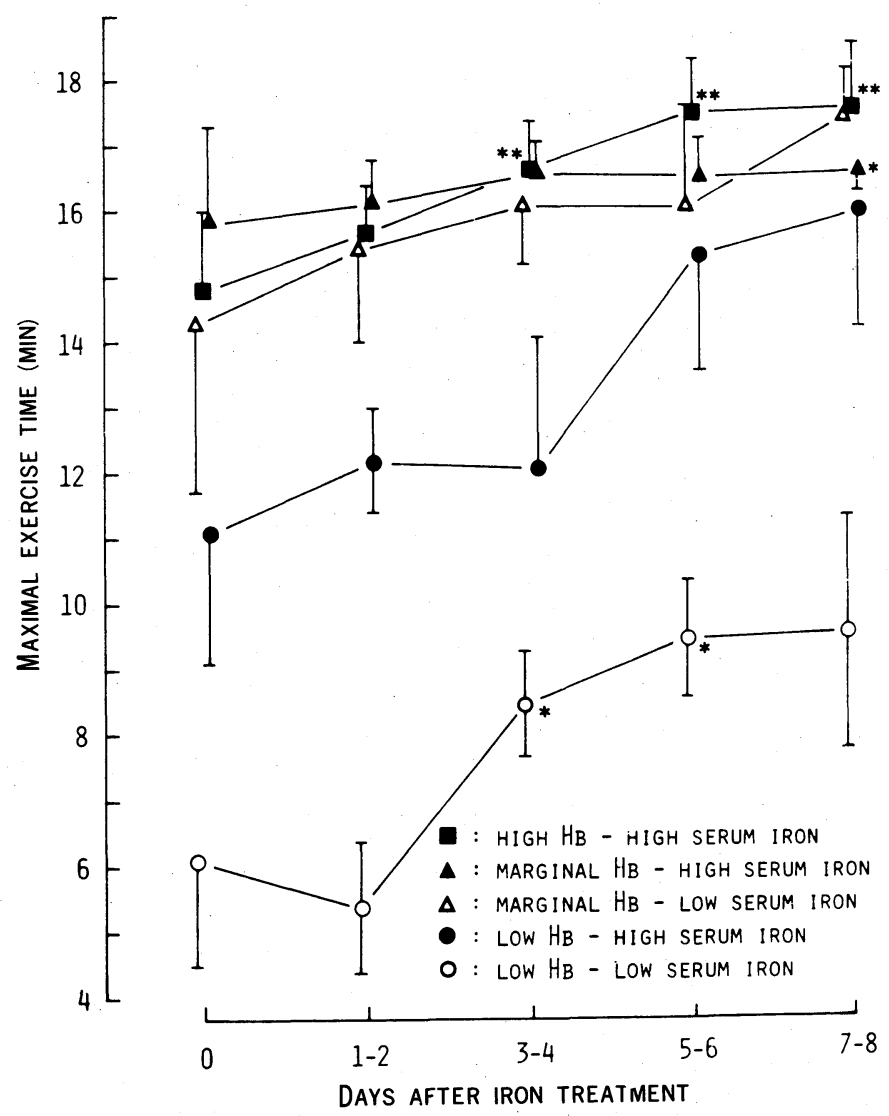

Fig. 2. Changes in mean maximal work capacity in response to iron treatment $\left( \pm\right.$ SEM). ${ }^{*} p<0.05$ and ${ }^{* *} p<0.01$ by paired $t$-tests between the values before and each day after treatment. Initial work time in the low Hb-low serum iron group was significantly less than the high $\mathrm{Hb}$-high iron, marginal Hb-high iron $(p<0.01)$ and marginal Hb-low iron groups $(p<0.05)$.

2). As was shown by Finch et al. (12) in rats, we found a close relationship between blood lactate and work time $(r=0.53, p<0.01)$ for the subjects with low or marginal $\mathrm{Hb}$ levels.

\section{DISCUSSION}

A number of observations have been made suggesting that in addition to $\mathrm{a} \mathrm{Hb}$ effect on maximum work capacity, there is also an effect not related to $\mathrm{Hb}$ $(2,5,6,13,14)$. For example, Ericsson (13) reported an elevated maximum rate of oxygen consumption with iron treatment in normal subjects even though there was no elevation in $\mathrm{Hb}$. Finch et al. (2) reported that if a rat was iron deficient and 


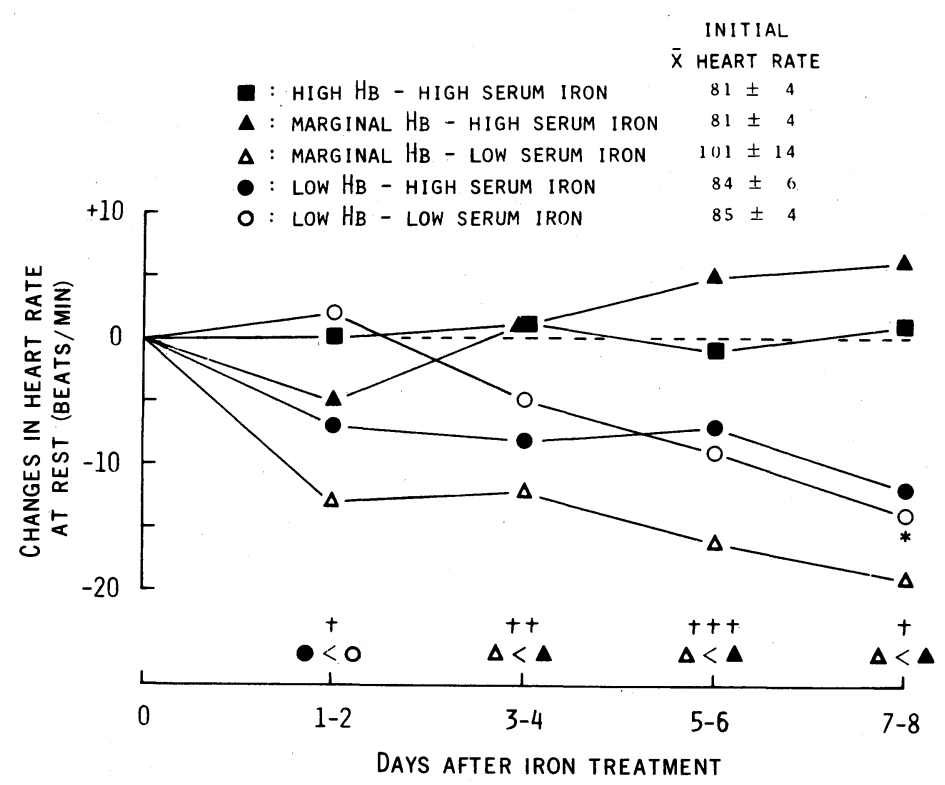

Fig. 3. Changes in mean heart rate at rest in response to iron treatment. ${ }^{\dagger} p<0.05,{ }^{\dagger \dagger}$ $p<0.01$ and ${ }^{1+\dagger} p<0.001$ by unpaired $t$-tests between high and low serum iron groups with the same $\mathrm{Hb}$ levels. ${ }^{*} p<0.05$ by a paired $t$-test between pre-treatment base line (broken line) and each day after treatment.

anemic and was transfused with red blood cells to elevate $\mathrm{Hb}$ to a moderate level $(10 \mathrm{~g} / 100 \mathrm{ml})$ the transfused rat would perform no better than the iron-deficient and anemic rat $(6 \mathrm{~g} / 100 \mathrm{ml})$. Ohira et al. $(5,6)$ have shown that the heart rate response of iron-deficient anemic humans to iron treatment cannot be totally accounted for by changes in $\mathrm{Hb}$. The data reported in this paper are certainly consistent with at least an initial and minor beneficial effect of iron treatment that cannot be related to changes in $\mathrm{Hb}$. It was found that even normal rats absorbed greater amounts of ${ }^{59} \mathrm{Fe}$ in cardiac muscle within 4 days after oral treatment (unpulished data). Our current data showed that this effect is more significant in iron-deficient groups than in normal iron groups even though both groups had similar $\mathrm{Hb}$ levels. Bradycardial effect of iron was also evident at rest as well as during exercise. Not only was the heart rate response to exercise lowered in subjects with low serum iron following treatment, but the length of time that anemic subjects with low serum iron could work on the treadmill was also less than the work time in the anemic subjects with high serum iron. Based on our previous population data (3) with $\mathrm{Hb}$ levels between 6 and 7 (low serum iron and low $\mathrm{Hb}$ ), 7 and 8 (high serum iron and low $\mathrm{Hb}$ ) and 11 and $12 \mathrm{~g} / 100 \mathrm{ml}$ (low serum iron and moderate $\mathrm{Hb}$ ), these subjects should have exercised 10,12 and $14 \mathrm{~min}$, respectively. They actually exercised 6,11 and $14 \mathrm{~min}$ at day 0 (Fig. 2). On day 7-8 they lasted for 10,16 and $18 \mathrm{~min}$, each being about $4 \mathrm{~min}$ longer than would be expected on the basis of their $\mathrm{Hb}$. In contrast, the 


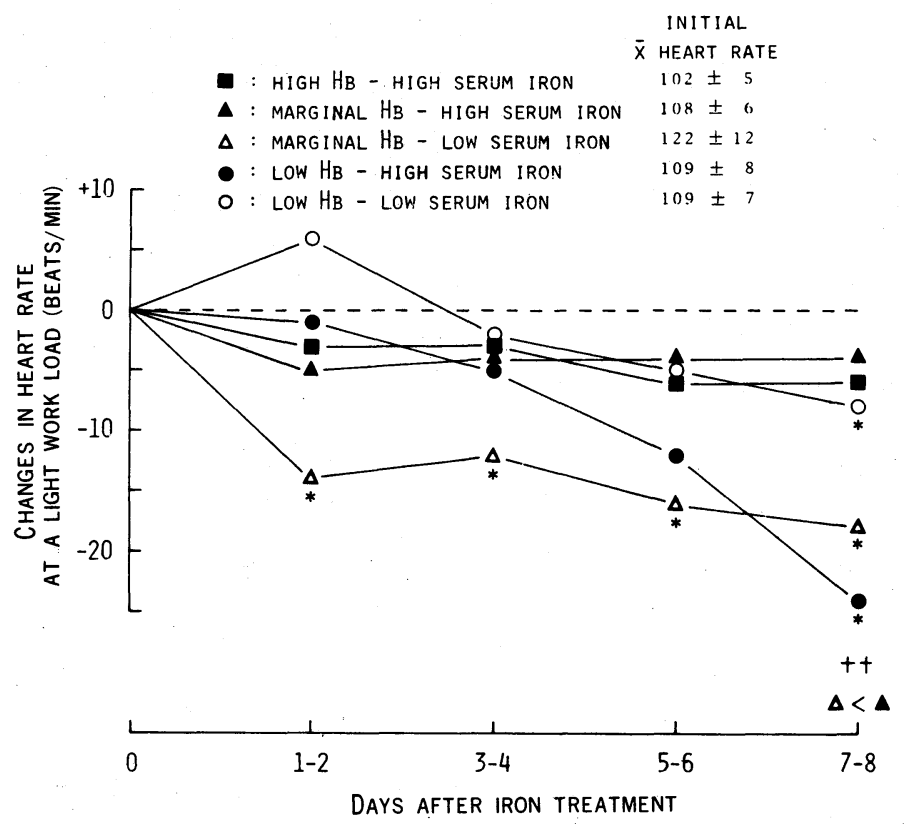

Fig. 4. Changes in mean heart rate at a given light work load in response to iron treatment. ${ }^{\dagger \dagger} p<0.01$ by unpaired $t$-tests between high and low serum iron groups with the same $\mathrm{Hb}$ levels. ${ }^{*} p<0.05$ by paired $t$-tests between pre-treatment base line (broken line) and each day after treatment.

two groups with high serum iron and high or marginal $\mathrm{Hb}$ lasted for the exact time that would be predicted on the basis of $\mathrm{Hb}$ alone. The effects of individual life style and dietary habits on hematological and physiological parameters were controlled in the current study since all subjects remained hospitalized throughout the study.

In addition to the non- $\mathrm{Hb}$ effects of iron treatment it is clear that $\mathrm{Hb}$ itself is a major determinant of work performance. For example, when an iron-deficient and anemic subject is transfused with whole blood, the improvement in work tolerance was exactly as would be predicted by the new $\mathrm{Hb}$ level alone (15) based on work performance tests of a large population of tea pluckers from Sri Lanka (3), as well as by other "control" subjects with the same $\mathrm{Hb}$ and who had that $\mathrm{Hb}$ level for perhaps weeks (15). Based on the studies on young rats (2), it would be predicted that no improvement in work capacity should have occurred in iron-deficient anemic subjects when the $\mathrm{Hb}$ was elevated by whole blood transfusion. This apparent discrepancy in the relative importance of $\mathrm{Hb}$ and non-Hb factors may be due to the difference in age when an iron-deficient diet is introduced (16).

It appears that the non-Hb related benefit that can be obtained 3-16 days after iron treatment does not continue indefinitely. For example, subjects that had their $\mathrm{Hb}$ elevated from about 7 to $9 \mathrm{~g} / 100 \mathrm{ml}$ by Imferon treatment had a lower heart rate response to exercise 16 days after treatment(5). Their heart rate responses were Vol. 27, No. 2, 1981 


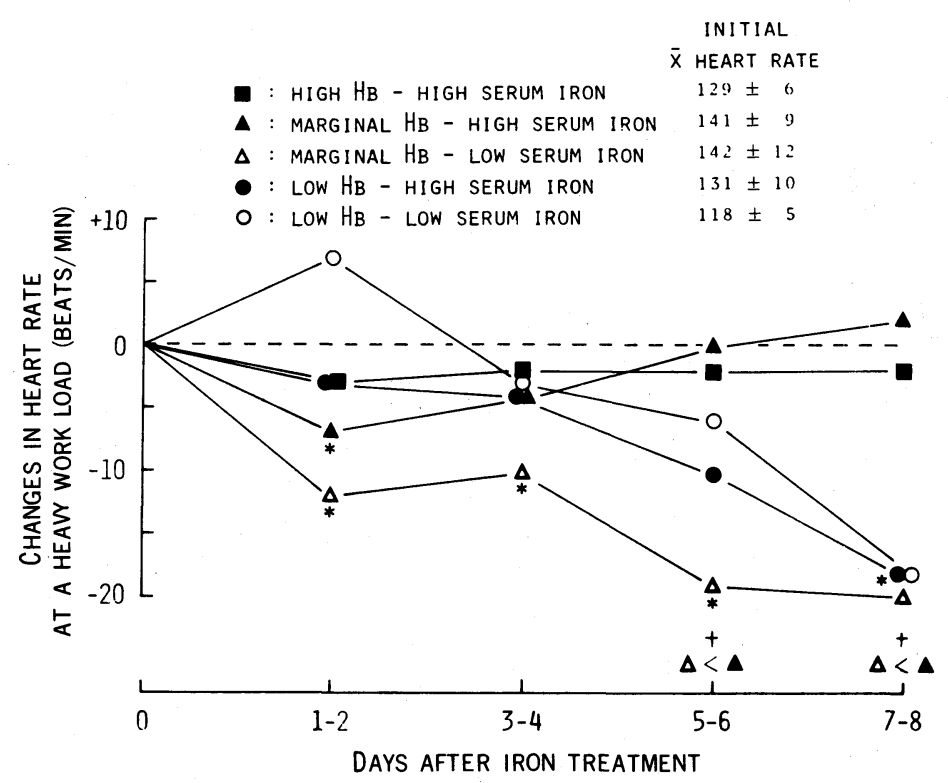

Fig. 5. Changes in mean heart rate at a given heavy work load in response to iron treatment. ${ }^{\dagger} p<0.05$ by unpaired $t$-tests between high and low serum iron groups with the same $\mathrm{Hb}$ levels. ${ }^{*} p<0.05$ by paired $t$-tests between the values before (broken line) and each day after treatment.

similar to subjects with $\mathrm{Hb}$ of $13 \mathrm{~g} / 100 \mathrm{ml}$, but who had not received iron supplements. A temporary nature of the iron treatment effect is also suggested by the comparisons of the work performance at a given $\mathrm{Hb}$ level within the first week of iron treatment, as pointed out in the preceding paragraph.

Post-exercise venous blood lactate data also suggest a non-Hb related effect (Table 2). The three groups, high $\mathrm{Hb}$-high iron, marginal Hb-high iron, and marginal Hb-low iron, had almost identical maximal work capacities, thereby eliminating work time on a variable in affecting blood lactate. The coefficient of correlation $(r=-0.41, p<0.05)$ between serum iron and lactate levels after exercise suggests that the lower the serum iron the higher the blood lactate after exercise. If we compare the post-exercise lactate levels of two groups with approximately the same $\mathrm{Hb}$ level, but one with low iron and the other with high iron levels, significantly higher post-exercise blood lactate occurs in the low iron group even though the intensity and duration of exercise was similar. These results are consistent with results obtained from rats (12).

These data provide evidence that a non-Hb related and beneficial effect of iron supplementation occurs in iron-deficient and anemic humans. It is also suggested that the effect occurs rather quickly, is perhaps temporary, and the magnitude of the effect is not as great as that which can be expected to occur as a result of elevating the $\mathrm{Hb}$. 


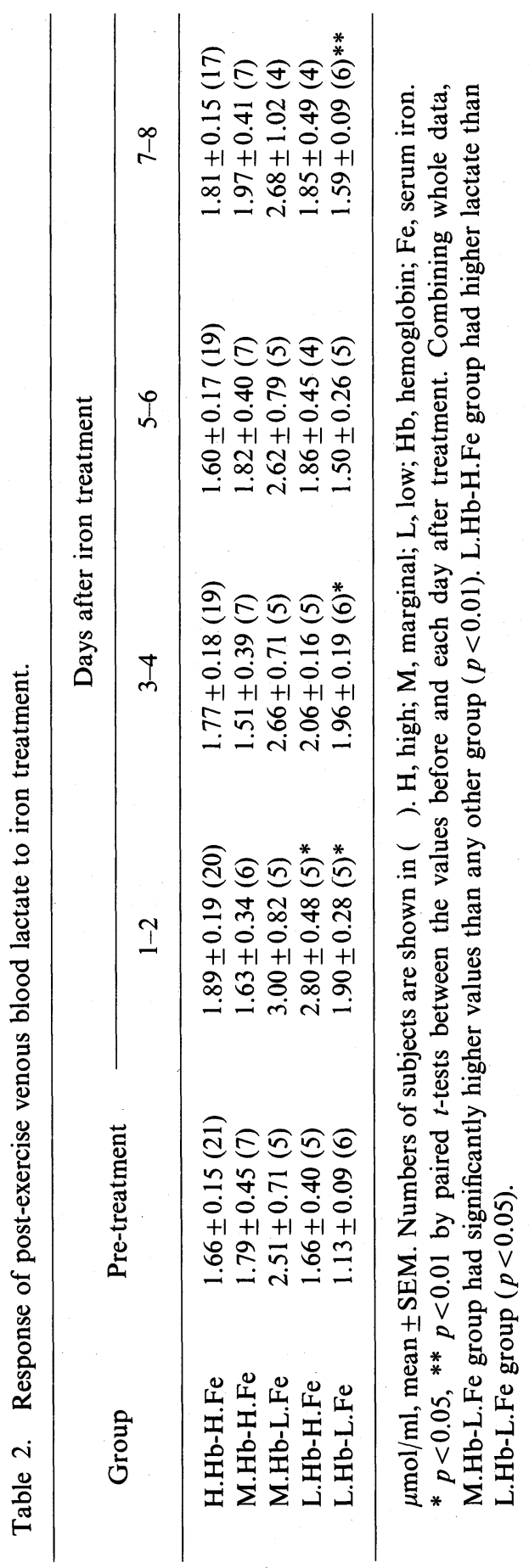


This study was supported in part by the USPHS Biomedical Research Grant and J. B. Williams Comapany, Inc., New York. The authors wish to acknowledge the technical assistance of Ms. H. Perera, Mr. G. A. Senewiratne and medical technicians in the Jikei University Hospital.

\section{REFERENCES}

1) Edgerton, V. R., Bryant, S. L., Gillespie, C. A., and Gardner, G. W. (1972): Iron deficiency anemia and physical performance and activity of rats. J. Nutr., 102, 381-399.

2) Finch, C. A., Miller, L. R., Inamdar, A. R., Person, R., Seiler, K., and Mackler, B. (1976): Iron deficiency in the rats. Physiological and biochemical studies of muscle dysfunction. J. Clin. Invest., 58, 447-453.

3) Gardner, G. W., Edgerton, V. R., Senewiratne, B., Barnard, R. J., and Ohira, Y. (1977): Physical work capacity and metabolic stress in subjects with iron deficiency anemia. Am. J. Clin. Nutr., 30, 910-917.

4) Viteri, F. E., and Torun, B. (1974): Anaemia and physical work capacity. Clin. Haematol., 3, 609-626.

5) Ohira, .Y., Edgerton, V. R., Gardner, G. W., Senewiratne, B., Barnard, R. J., and Simpson, D. R. (1979): Work capacity, heart rate and blood lactate responses to iron treatment. Br. J. Haematol., 41, 365-372.

6) Ohira, Y., Edgerton, V. R., Gardner, G. W., Senewiratne, B., and Simpson, D. R. (1978): Non-hemoglobin related effects on heart rate in iron deficiency anemia. Nutr. Rep. Int., 18, 647-651.

7) Levy, A. L., and Vitacca, P. (1961): Direct determination and binding capacity of serum iron. Clin. Chem., 7, 214-248.

8) Kalinowska, B. (1978): Serum haptoglobin level in the differential diagnosis of jaundice. Przeg. Epid., 32, 215-224.

9) Gutmann, I., and Wahlefeld, A. W. (1974): L-(+)-Lactate determination with lactate dehydrogenase and NAD, in Methods of Enzymatic Analysis, Vol. 3, 2nd ed., ed. by Bergmeyer, H. U., Academic Press, New York, pp. 1464-1468.

10) Ashida, T., Yamada, T., and Yoshimura, H. (1972): Effect of protein nutrition on the Hb-binding capacity of haptoglobin in the muscular training. Eiyo To Shokuryo (J. Jpn. Soc. Food Nutr.), 25, 633-639.

11) Laurell, C.-B., and Nyman, M. (1957): Studies on the serumhaptoglobin level in hemoglobinemia and its influence on renal excretion of hemoglobin. Blood, 12, 493-506.

12) Finch, C. A., Gollnick, P. D., Hlastala, M. P., Miller, L. R., Dillmann, E., and Mackler, B. (1979): Lactic acidosis as a result of iron deficiency. J. Clin. Invest., 64, 129-137.

13) Ericsson, P. (1970): The effect of iron supplementation on the physical work capacity in the elderly. Acta Med. Scand., 188, 361-374.

14) Jacobs, A. (1977): The non-haematological effects of iron deficiency. Clin. Sci. Mol. Med., 53, 105-109.

15) Edgerton, V. R., Ohira, Y., Hettiarachchi, J., Senewiratne, B., Gardner, G. W., and Barnard, R. J. (1981): Elevation of hemoglobin and work tolerance in iron-deficient subjects. J. Nutr. Sci. Vitaminol., 27, 77-86.

16) Koziol, B. J., Ohira, Y., Simpson, D. R., and Edgerton, V. R. (1978): Biochemical skeletal muscle and hematological profiles of moderate and severely iron deficient and anemic adult rats. J. Nutr., 108, 1306-1314. 